\title{
THE EFFORT OF THE HOMEROOM TO IMPROVE STUDENT'S READING INTEREST IN MIN 7 ACEH BARAT
}

\author{
Miswar $^{1}$, Herman Herman ${ }^{2}$, Khairuddin Hasan ${ }^{3}$, Rahmat Malikun ${ }^{4}$ \\ UIN Sumatera Utara ${ }^{2}$, STAIN Teungku Dirundeng Meulaboh ${ }^{2,3,4}$ \\ miswar@uinsu.ac.id, herman@staindirundeng.ac.id
}

\begin{abstract}
The homeroom teacher is a very influential figure in an effort to increase students' interest in reading. Because the homeroom teacher is the closest party to the students and always guides, monitors, and motivates them to learn. This study aims to determine the efforts of homeroom teachers in increasing students' reading interest. This study used descriptive qualitative method. The subjects in this study were the principal and three homeroom teachers. Data collection techniques with interviews, observation and documentation. Data analysis techniques in this study used data reduction, data presentation and drawing conclusions. Based on the results of the study, it can be concluded that the homeroom's efforts in increasing interest in reading are pursued by motivating student learning. Students are encouraged to read by borrowing books from the library. In addition, in the learning process, the teacher also asks students to read one by one so that students are able to respond to the material given by the teacher. The teacher also coordinates with parents in order to increase students' reading interest. Coordination is done by asking the implementation of student guidance at home and asking parents to control their children's reading behavior at home.
\end{abstract}

Keywords: Effort, Homeroom, Interest in Reading,

\begin{abstract}
Abstrak
Wali kelas merupakan sosok yang amat berpengaruh dalam upaya meningkatkan minat membaca siswa. Karena wali kelas pihak yang paling dekat dengan siswa dan selalu membimbing, memantau, dan memotivasi untuk belajar. Penelitian ini bertujuan untuk mengetahui upaya wali kelas dalam meningkatkan minat membaca siswa. Penelitian ini menggunakan metode deskriptif kualitatif. Subjek dalam penelitian ini adalah kepala sekolah dan tiga orang wali kelas. Teknik pengambilan data dengan wawancara, observasi dan dokumentasi. Teknik analisis data dalam penelitian ini menggunakan reduksi data, penyajian data dan penarikan kesimpulan. Berdasarkan hasil penelitian dapat disimpulkan bahwa upaya wali kelas dalam peningkatan minat membaca ditempuh dengan memotivasi belajar siswa. Siswa didorong untuk membaca dengan meminjam buku di perpustakaan. Selain itu dalam pembelajaran berlangsung guru juga meminta siswa untuk membaca satu persatu agar siswa mampu menanggapi materi yang diberikan oleh guru. Guru juga melakukan koordinasi dengan para orang tua dalam rangka meningkatkan minat baca siswa. Koordinasi dilakukan dengan cara menanyakan pelaksanapembimbingan siswa di rumah dan menanyakan pengontrolan perilaku membaca anak oleh orang tua di rumah.
\end{abstract}

Kata kunci: Upaya, Wali Kelas, Minat Membaca. 


\section{INTRODUCTION}

The teacher is one of the factors that will determine the success of a teaching and learning process. The homeroom's efforts in this case are very influential on the educational process, because the homeroom's efforts are very dominant in students' reading interest, and the teaching ability of a teacher who has the duty as homeroom teacher must have professional competence so that an effective and efficient learning process is created.

The homeroom teacher is a teacher who is trusted by the principal to manage the class and control students in the teaching and learning process, therefore the homeroom's efforts are very important in the interest of students to foster and direct their students in achieving the desired achievement. The task and function of the homeroom teacher in this case is to move students, influencing, guiding, motivating, directing, creating conditions and environments that are conducive to each other so that the class becomes a learning community that can advance together in the learning process.

Children who have an interest in certain subjects tend to give greater attention to these subjects. Interest can be interpreted as a sense of interest shown by students in carrying out learning activities, both at home, at school, and in the community. If the child feels interested or interested in doing activities, then the child shows good attitudes and behavior, namely the child shows a high passion in carrying out these activities (Slameto, 2003).

Interest in something is basically helping children see how the relationship between the material they are expected to learn and themselves as individuals is. This process means showing the child how certain knowledge or skills affect him, serve his goals, satisfy his needs. If the child realizes that learning is a tool to achieve some goals that he considers important, and if the child sees that the results of his learning experience will bring progress to him, he will most likely interested (and motivated) to learn it.

Reading is a complex activity with a large number of directives with discrete actions. Includes: people who have to use understanding and imagination, observe and remember. We cannot read without moving our eyes or without using our minds. Comprehension and speed of reading become very dependent on the ability to carry out every organ of the body needed for it.

Increasing interest in reading must begin with self-motivation in reading, so that it can trigger the importance of reading for students and the community. Therefore, by reading, the 
views of students and the public are open to new things that were not known before. Interest is a strong urge to do something without coercion. In learning there are several things that can affect students' interest in learning, so an educator must be able to turn a boring learning process into an exciting learning experience (Farida, 2008).

This study aims to explore information about the homeroom's efforts in increasing student interest in reading at MIN 7 Aceh Barat. Another goal is to find out the homeroom's efforts in motivating students to increase their interest in reading. In addition, the study also aims to determine the efforts of homeroom teachers in coordinating with parents in order to increase students' reading interest.

Term restrictions are used to avoid ambiguity in understanding the diction used. The homeroom teacher referred to in this study is an adult who is consciously responsible for educating, teaching, and guiding students. People who are called teachers are people who have the ability to design learning programs and are able to organize and manage classes so that students can learn and in the end can reach the level of maturity as the ultimate goal of the educational process.

While interest is a person's tendency towards something or it can be said what someone likes to do. Basically, everyone will prefer to do something that suits their interests (which they like) rather than doing something they don't like (Lusi, 2008).

\section{THEORITICAL REVIEW}

\section{A. Homeroom Teacher}

The teacher is the spearhead in the teaching and learning process, because it is the teacher who interacts directly with students in the classroom. It is the teacher who plays a very important role in making students understand and understand the subjects being taught. Schools as educational institutions need teachers who not only function as teachers who teach certain subjects to their students, but also as educators who provide knowledge to their students about ethics, the ability to survive in life, morals, ethics, creation and so on (Pupuh, 2012).

On several occasions, a teacher often gets additional assignments as homeroom teacher. Without eliminating the main task, the homeroom teacher has a greater responsibility than just carrying out learning to students. 
The homeroom teacher has a very big role in classroom management. The homeroom teacher is actually an encouragement for the development of progress in the classroom. They are responsible for the success or failure of the class community for which they are responsible (Doni, 2007).

The results of the homeroom's performance can be seen how he becomes an example for the class as a community of shared learning. Homeroom teachers usually also become teachers in certain fields of study, but they have other duties as the person in charge of the dynamics of learning in certain classes. The most prominent role of the homeroom teacher is to be a kind of head of the family in a class, this means that he is primarily responsible for creating conditions and an environment that is conducive to each other so that the class becomes a learning community that can move forward together in the learning process (Nasir, 2012).

The main task of the homeroom teacher is to make the class comfortable so that students can study comfortably. The homeroom teacher must also be able to create beautiful and fun classes so that a learning process can run effectively and efficiently, so that students will find it easy and comfortable to read. The homeroom teacher can also act as a teacher, parent, friend who can manage and organize the class in an appropriate atmosphere.

In the beginning, the assignment as homeroom teacher was the most important part, because the first impression, after all, would have an impact on the continuity of the next relationship. At the initial meeting, discuss with the target class, what kind of conducive class you want to create together, then set the class vision and mission as well as class organization tools, agree on the rules of the game related to inculcating values, for example instilling in the target class the discipline of attending. Tell the class that every individual in the class has meaning for the class so that if they are not present, they must inform the homeroom teacher either via cell phone or by telephone, and only after entering in the future, the student submits a letter of permission directly to the homeroom teacher (Suparlan, 2004).

The homeroom teacher has several functions in carrying out his duties. Manager, a homeroom teacher must be able to be a good manager, because he must prioritize his managerial function when students have to fulfill something that has been set. Motivator, a homeroom teacher must be able to be a good motivator, because he must know the weaknesses and strengths of each student so that the homeroom teacher is able to direct 
students according to their abilities and optimize the potential of their students (Woolfock, Weinstein, 2006).

Designer, a homeroom teacher must have good ideas for the class he manages, he has plans that may be achieved and how to achieve them by involving all the potential of the class he has. Administrator, a homeroom teacher must be able to become a great administrator, because the value of students is at stake if the homeroom teacher does not have expertise in certain administrator fields it will hinder and harm students. Psychologists, a homeroom teacher must be able to read the situations and conditions that are faced, he can feel what students feel and then provide advice and solutions in dealing with student problems (Woolfock, Weinstein, 2006).

Other roles that must be performed by the homeroom teacher are as follows:

1. As the closest person to students in a school, in addition to being a teacher;

2. As a subject teacher;

3. Homeroom teachers must be able to develop empathy in order to work with students whose lifestyles and cultures are different from those of the teacher;

4. Homeroom teachers are able to understand the importance of the affective domain in increasing student interest and responsible behavior;

5. Homeroom teachers are aware of students' experiences, both outside and inside school, and understand the contexts that shape their experiences (Mintchell, 2012).

\section{B. Students' Reading Interest}

Interest in reading is a mental tendency to encourage someone to do something about reading. Interest in reading is indicated by a strong desire to carry out reading activities. The author strongly agrees with the statement above, by fostering interest in reading in early childhood, it will have an impact on increasing children's interest in reading. In this case, children's interest in reading will increase if they are often faced with reading that suits their needs. Therefore, parents need to motivate their children and at the same time accept them reading (Darmono, 2004).

Interest is one of the factors that influence a person's business. A strong interest will lead to serious, persistent effort and not easily discouraged in the face of challenges. If a student wants to learn, he will quickly be able to understand and remember it. 
Interests affect the shape of the intensity of the ideals. For example, a child who is interested in sports has a goal of becoming an accomplished sportsman, while a child who is interested in physical health has a dream to become a doctor. A person's interest even though he is taught by the same teacher and given a lesson, but from one child to another he gets a different amount of knowledge. This happens because their absorption is different and this absorption is influenced by the intensity of their interest.

The function of greater interest is as a motivating force, namely as a force that encourages students to do something. Students who are interested in learning will appear to be driven to continue to study diligently, in contrast to students whose attitude is only to accept lessons. They only move to want to learn but it is difficult to continue to persevere because there is no support. From some of the opinions above, it can be concluded that to get good results, a student must have an interest so that it will encourage him to keep trying (Triatma, Ilhamnur).

Factors that can affect reading interest based on the description above are the provision of time for reading, family environmental factors and the environment outside the family can affect a person's reading interest. Provision of time to read is related to taking time to read. Family environmental factors are related to parents who do not like to read and do not set an example for their children to get used to reading. Environmental factors outside the family are related to the child's social environment, schools that are not supportive, and the price of expensive books (Triatma, Ilhamnur).

The indicators to find out whether someone has a high or low interest in reading is the frequency and quantity of reading. Students who have an interest in reading will often read more, and vice versa. People who have an interest in reading will try to read a variety of readings. They not only read the literature they need at that time but also read the literature they deem important (Dalman, 2014).

There are several ways to foster interest in reading, namely:

1. Encourage children to tell stories about what they have heard or read.

2. Take the child to the bookstore/library. The library will introduce children to the diversity of reading materials so that they foster a great sense of curiosity to read the reading materials they see, the availability of reading materials allows the child to choose readings that match their interests and interests so as to foster interest in reading. 
3. Buy books that interest children. An interesting book will certainly give a response to the child to open or read a book that interests him.

4. Create a family library. The availability of various reading materials will create conditions for consuming books every day as a basic need in daily life.

5. Eliminate obstacles such as television or playstation. It is difficult to create interest in reading in children because of the influence of watching television, playstation, and other things that children like. The role of parents and teachers is very important to encourage children to enjoy reading with various tasks related to reading so that they are accustomed to loving reading materials.

6. Give gifts (rewards) that increase the spirit of reading. A response is elicited by a stimulus. Gifts are a stimulus to elicit a response in children to be more active in reading.

7. Make the book as a gift (reward) for children. Someone will assume a gift is a very important gift, so the recipient of the gift is required to appreciate the purchase or gift from others. In this case, the gift giver will feel happy when the gift recipient reads the book he has given.

8. Make reading activities a daily activity. If someone is accustomed to reading, then reading will become a necessity that must be consumed every day.

9. Increasing interest in reading can be done by adjusting reading materials to the needs of children.

10. Provide reading time. Providing time in reading is certainly very important because in this case it will foster a regular reading activity in the midst of daily busyness (Dalman, 2014).

\section{METHOD}

This research is descriptive qualitative. This research only looks at the state of the object or problem and is not intended to draw generally accepted conclusions. The research was conducted in MIN 7 Aceh Barat. The research was conducted in 2020. The resource persons were determined by purposive sampling technique. The resource persons consisted of homeroom teachers and school principals. Data collection techniques using interviews, observation and documentation. Data analysis using data reduction techniques, data presentation and drawing conclusions. 


\section{RESULT AND DISCUSSION}

\section{A. Homeroom Efforts to Increase Students' Reading Interest}

The task of the homeroom teacher is to move students by influencing, guiding, motivating students to act or behave in accordance with the goals to be achieved in teaching and learning activities. The homeroom teacher does not only guide and motivate students, but the homeroom teacher also has duties and functions in managing a class, so that a teaching and learning process can run effectively and students are also enthusiastic about reading.

There are several steps that can be taken by teachers to increase students' motivation to read, such as: preparing books in the library and asking students to read one by one. Based on the statement above, we can also see from the results of the researcher's interview with the homeroom teacher as follows. The homeroom teacher named Siti said, "Actually, the children are not instructed to do so, because when the teacher gives assignments in the textbooks, the children automatically borrow books. There are those who have their own books and then there are also those whose books are usually returned. If we look now, there are very few books with the theme of religious studies. The rules for religious lessons change automatically every year, so we have to buy a new book and now thank God there is a new book, but for other subjects with general themes, most of the children's books already exist, even now we are instructed not to write a lot because children -Children read more in books because all the lessons are in books and then they are not written back just to be studied and read."

The homeroom teacher named Rasanah said, "The children have their own initiative even though we don't ask students, they still borrow books from the library, every break the children go to the library to borrow books, and they read. Then they borrow books too to take home." So at MIN 7 Aceh Barat, there is no need to be instructed, but there is self-awareness from students who always borrow books from the library.

When asked whether the homeroom teacher ever ordered students to read one by one. The homeroom teacher named Muhammad Fauzi said "Once and very often, but there are some students who are lazy in reading, and the teacher always motivates the students to be active in reading so that the material given by the teacher can be responded to." So the teacher always asks students to read and borrow books in the library, but the obstacle in reading comes from the students who are less interested in reading and the teacher always provides motivation so that students' interest in reading is more increased than before. 
So the homeroom's efforts in motivating students to increase student interest in reading at MIN 7 Aceh Barat are always encouraging students to read by asking students to borrow books from the library and in the learning process the teacher also asks students to read one by one so that students are able to respond to the material provided.

The homeroom teacher plays an active role in providing an injection of enthusiasm and motivation in increasing students' reading interest, this can be seen when the homeroom teacher gives direction to students during the teaching and learning process, so that the learning process to increase interest in reading can run well and students are enthusiastic in read.

Then another effort made by the homeroom teacher in increasing interest in reading is to maintain the cleanliness of the classroom so that the teaching and learning process and reading are more comfortable and enthusiastic. In addition, the seats are also arranged to make it easier to read and easy to detect students who feel uncomfortable if sitting behind. Sitting positions are also rotated by providing opportunities for students sitting at the back to move to the front.

The homeroom's efforts are very important as a support so that students are enthusiastic about learning and being creative in school. Because the homeroom teacher is a resource for knowledge, the homeroom teacher is also a motivator for students in learning and enhances the development of students' mindsets. And besides the homeroom teacher, there is one other party that is also important for increasing students' reading interest, the other party is the principal, because this principal can be a motivator for the development of students' mindsets.

Those who are indeed a support in building students' reading interest are the teachers at the school, school staff and school picket teachers. If the school community does not work together to form a pattern of student enthusiasm in reading, students may not be able to achieve maximum success in reading. Students also have a very important role to be a supporter so that students are enthusiastic about reading, because if students themselves are lazy in doing reading activities, so the results of the homeroom and principal's efforts in encouraging or improving students' reading will not work optimally and will not be achieved.

And the homeroom's efforts in motivating students to increase students' interest in reading are always encouraging students to read by asking students to borrow books in the 
library and in the learning process the teacher also asks students to read one by one so that students are able to respond to the material provided by the teacher.

\section{B. The Teacher's Efforts to Coordinate with Parents to Increase Students' Reading Interest}

The role of parents is also important in the process of children's education. The success of the teaching and learning process cannot only be imposed on the teacher alone. Parents must play an active role in the child's learning process. In essence, parents are the main factor for a child in getting an education. Meanwhile, teachers and schools are further madrasas for students. Providing support to students in the learning process is one example of motivation that parents can do for their children.

According to the reality that there are still many parents who do not know how to support students in achieving their dreams. In terms of raising parents' awareness of the importance of their role in determining the success of children/students, teachers can help by providing positive and informative suggestions or input to parents. No parent wants to see their children fail now or in the future. However, not all parents are aware that they have a significant role in determining the success of their children.

Parents should often ask their children how their learning progress at school, and control children's reading at home so that children's interest in reading increases. Teacher interaction with parents is very important because parents are very responsible for student learning at home. The role of parents is also important in the process of children's education. The success of the teaching and learning process cannot only be imposed on the teacher alone.

In motivating parents by the homeroom teacher is very important, because in this way the teacher can find out whether or not there are problems faced by students, so that students are not disturbed in improving reading, besides motivating parents by the homeroom teacher can be a bridge for the homeroom. in interacting and approaching students' parents, in order to be a support in improving students' reading by the homeroom teacher.

When asked if the teacher had ever communicated with parents regarding the availability of children's reading materials at home, some homeroom teachers said that there had been direct communication. And homeroom teachers also often ask parents of students but are not forced to buy reading books. 
The homeroom teacher also communicates with parents to ensure that control measures are in place to increase students' reading interest at home. Communication is done directly but not face-to-face. It is hoped that with intensive communication, parents' awareness will emerge to pay more attention to their children's reading interest.

\section{CONCLUSION}

Increasing students' motivation towards increasing student interest in reading at MIN 7 Aceh Barat can be done by encouraging students to read by asking students to borrow books from the library and in the learning process the teacher also asks students to read one by one so that students are able to respond to the material provided by the teacher. Coordination between teachers and parents is done in order to increase students' reading interest. Based on the results of the coordination, parents also guide their children in reading. In addition, parents also provide quality reading materials for their children.

\section{REFERENCES}

Dalman, Keterampilan Menulis, Jakarta: PT. Raja Grafindo Persada, 2014.

Triatma dan Ilham Nur, Minat Baca Pada Siswa VI Sekolah Dasar Negeri

Delegan 2 Prambanan Sleman, Yogyakarta: E-Jurnal Prodi Teknologi

Pendidikan. Vol. V Nomor 6.

Darmono, Manajemen dan Tata Kerja Perpustakaan Sekolah, Jakarta: Gramedia

Widia Sarana Indonesia, 2004.

Slameto, Belajar Dan Faktor-Faktor Yang Mempengaruhinya, Jakarta: Renika Cipta. 2003.

Farida Rahim, Pengajaran Membaca di Sekolah, Jakarta: Bumi Aksara, 2008.

Lusi Nuryanti, Psikologi Anak, ( Jakarta: PT Indeks, 2008)

Doni Koesoema Albertus, Pendidikan dan Strategi Mendidik Anak di Zaman Global, (Jakarta: Grasindo, 2007)

Nasir Usman, Manajemen Peningkatan Mutu Guru, (Bandung: Cipta Pustaka Media Perintis, 2012)

Suparlan, Mencerdaskan Kehidupan Bangsa dari Konsepsi sampai dengan Implementasi, (Yogyakarta: Hikayat Publising, 2004)

Woolfock dan Weinstein, Manajemen Kelas Berbasis Komprehensif, (Jakarta: Kencana Prenada Media Grup, 2006)

Mintchell, Manajemen Kelas Bebasis Implementasi, Edisi Kesembilan, (Jakarta: Perpustakaan Nasional, Katalog dalam Terbitan, 2012) 